\title{
Artificial root exudates and soil organic carbon mineralization in a degraded sandy grassland in northern China
}

\author{
YongQing LUO ${ }^{1,2^{*}}$, XueYong ZHAO ${ }^{1}$, Olof ANDRÉN ${ }^{1,3}$, YangChun ZHU ${ }^{1,2}$, WenDa HUANG ${ }^{1}$ \\ ${ }^{1}$ Naiman Desertification and Farmland Research Station of the Cold and Arid Regions Environmental and Engineering \\ Research Institute, Chinese Academy of Sciences, Lanzhou 730000, China; \\ ${ }^{2}$ University of Chinese Academy of Sciences, Beijing 100049, China; \\ ${ }^{3}$ Bjorklundavagen 3, SE-756 46 Uppsala, Sweden
}

\begin{abstract}
Plant root exudates contain various organic and inorganic components that include glucose, citric and oxalic acid. These components affect rhizosphere microbial and microfaunal activities, but the mechanisms are not fully known. Studies concerned from degraded grassland ecosystems with low soil carbon (C) contents are rare, in spite of the global distribution of grasslands in need of restoration. All these have a high potential for carbon sequestration, with a reduced carbon content due to overutilization. An exudate component that rapidly decomposes will increase soil respiration and $\mathrm{CO}_{2}$ emission, while a component that reduces decomposition of native soil carbon can reduce $\mathrm{CO}_{2}$ emission and actually help sequestering carbon in soil. Therefore, to investigate root exudate effects on rhizosphere activity, citric acid, glucose and oxalic acid $(0.6 \mathrm{~g} \mathrm{C} / \mathrm{kg}$ dry soil) were added to soils from three biotopes (grassland, fixed dune and mobile dune) located in Naiman, Horqin Sandy Land, Inner Mongolia, China) and subjected to a 24-day incubation experiment together with a control. The soils were also analyzed for general soil properties. The results show that total respiration without exudate addition was highest in grassland soil, intermediate in fixed dune and lowest in mobile dune soil. However, the proportion of native soil carbon mineralized was highest in mobile dune soil, reflecting the low $\mathrm{C} / \mathrm{N}$ ratio found there. The exudate effects on $\mathrm{CO}_{2}-\mathrm{C}$ emissions and other variables differed somewhat between biotopes, but total respiration (including that from the added substrates) was significantly increased in all combinations compared with the control, except for oxalic acid addition to mobile dune soil, which reduced $\mathrm{CO}_{2}-\mathrm{C}$ emissions from native soil carbon. A small but statistically significant increase in $\mathrm{pH}$ by the exudate additions in grassland and fixed dune soil was observed, but there was a major decrease from acid additions to mobile dune soil. In contrast, electrical conductivity decreased in grassland and fixed dune soil and increased in mobile dune. Thus, discrete components of root exudates affected soil environmental conditions differently, and responses to root exudates in soils with low carbon contents can differ from those in normal soils. The results indicate a potential for, e.g., acid root exudates to decrease decomposition rate of soil organic matter in low carbon soils, which is of interest for both soil restoration and carbon sequestration.
\end{abstract}

Keywords: artificial root exudates; carbon mineralization; $\mathrm{pH}$ variation; deteriorated grassland ecosystem; Inner Mongolia

Citation: YongQing LUO, XueYong ZHAO, Olof ANDRÉN, YangChun ZHU, WenDa HUANG. 2014. Artificial root exudates and soil organic carbon mineralization in a degraded sandy grassland in northern China. Journal of Arid Land, 6(4): 423-431. doi: 10.1007/s40333-014-0063-z

The major pathway of carbon (C) inputs to soil is through plant litter-fall and roots, and the corresponding loss of carbon mainly occurs through microbial breakdown of soil organic matter. Since soil organic carbon (SOC) is the largest carbon sink in the terrestrial ecosystem, changes in the SOC pool size are di- rectly linked to changes in atmospheric $\mathrm{CO}_{2}$ concentration. Low molecular weight compounds (LMWC) that rapidly can be assimilated by the microbial community appear to be a main source in the total $\mathrm{CO}_{2}$ flux from soils, in spite of their low concentration at any given moment (van Hees et al., 2005; Glanville et

*Corresponding author: YongQing LUO (E-mail: luoyongqing8401@sina.com)

Received 2013-10-08; revised 2014-01-26; accepted 2014-02-17

(c) Xinjiang Institute of Ecology and Geography, Chinese Academy of Sciences, Science Press and Springer-Verlag Berlin Heidelberg 2014 
al., 2012). The LMWC are produced by the actions of extracellular enzymes on soil organic matter (SOM), or released directly into the soil from cellular lysis as well as via root and microbial exudation (Glanville et al., 2012). Microorganisms thus are greatly affected by plant root exudates, in both community growth (Ren et al., 2008) and individual growth ( Khan et al., 2011).

Root exudates are secreted by active roots during plant growth, and they have multiple effects in the plant-soil system (Gregory, 2006). Past studies have revealed that exudates can have complex chemistry and control biomass and activity of the rhizosphere microorganisms (Zhou et al., 2011). Root exudates are a complex mixture, including inorganic ions such as $\mathrm{K}^{+}, \mathrm{Na}^{+}, \mathrm{Ca}^{+}, \mathrm{Mg}^{2+}, \mathrm{NH}_{3}{ }^{+}, \mathrm{NO}_{4}{ }^{-}, \mathrm{SO}_{4}{ }^{2-}, \mathrm{H}_{3} \mathrm{PO}_{4}{ }^{2-}, \mathrm{Cl}^{-}$ etc., as well as organic compounds, e.g. sugars and polysaccharides, acids (amino acids, organic acids and fatty acids), sterols, growth factors, enzymes, flavonoids etc. (Gregory, 2006). There are many reported effects of root exudates, such as enhancing (Elhalmouch et al., 2006) or reducing (Hao et al., 2007) germination rates of seeds, increasing root peroxidase and superoxide dismutase activities, as well as enhancing membrane peroxidation (Yu et al., 2003). Sturz and Christie (2003) found that exudate production activates and sustains specific bacterial communities in the root zone, where bacteria generate secondary metabolites which can promote plant growth, increase the availability of minerals and nutrients, increase symbiotic nitrogen fixation rates, decrease susceptibility to frost damage, reduce phytopathogens by inducing systemic plant disease resistance, and facilitate plant establishment, growth and development. For a recent review of possible effects and outstanding questions concerning exudate effects, see Gärdenäs et al. (2011).

The methods used for studying root exudates can be divided into two groups. One is to view root exudates as a black box, only focusing on effects of complete exudates and evaluating differences between species (Yu et al., 2003; Elhalmouch et al., 2006). This method mimics the natural conditions, since plant root exudates are a complex mixture of compounds. However, due to the differing properties of the compounds, effects of single compounds are studied by the other methods, trying to find out the components, effects and fates of each compound in the root exudates. In- stead of extracting root exudates directly from plants, artificial root exudates are commonly used (Landi et al., 2006). The single compound approach allows for more detailed hypothesis testing, and was therefore selected for this study.

Soil carbon mineralization is influenced by additional inputs in soils; for instance legume residues markedly increase the rate and cumulative release of soil $\mathrm{CO}_{2}$-C emissions (Abera et al., 2012). In addition to the classical view of roots taking up only inorganic nutrients and water, there have been recent observations of root uptake of low molecular weight compounds for direct catabolic or anabolic use, but the magnitude of this pathway remains unclear (van Hees et al., 2005; Glanville et al., 2012).

Desertification and grassland deterioration are major problems in China. Restoration of sandy land is critical for the development of local economy and ecology. During the process of sandy land restoration from mobile dune to sandy grassland, soil physical and chemical properties vary greatly ( $\mathrm{Li}$ et al., 2006; Chen et al., 2012), which also is true for vegetation characteristics such as vegetation cover, species richness etc. (Zuo et al., 2012a). As a rule, both aboveground net primary productivity (ANPP) and belowground biomass increase by restoration (Li et al., 2006; Zuo et al., 2012a, b). Thus it is probable that root exudates will differ after restoration.

Studies of the ecological consequences of root exudate changes are rare, and there are few published reports on the effects of artificial root exudates such as glucose, oxalic acid and citric acid, which are main compounds of root exudates and play different roles in the plant/soil system. Glucose is a main source of carbon and is easily utilized by soil microorganisms (Strickland et al., 2012); citric and oxalic acids affect soil $\mathrm{pH}$ directly, which means that the environment for the microorganisms is rapidly changed (Rukshana et al., 2011, 2012). No reports have focused on the effects of these compounds in low-carbon sandy soils, such as those in Inner Mongolia. The objectives are to examine how rapidly these compounds decompose in the soils of three biotopes at different stages of restoration, and how they affect soil $\mathrm{pH}$ and electrical conductivity. This will add to the understanding of the rhizosphere process, and lay a foundation for future experiments. 


\section{Material and methods}

\subsection{Study area}

The study was conducted at the Naiman Desertification and Farmland Research Station of Chinese Academy of Sciences $\left(42^{\circ} 58^{\prime} \mathrm{N}, 120^{\circ} 43^{\prime} \mathrm{E}\right.$; $360 \mathrm{~m}$ asl), in the eastern part of Inner Mongolia, China. Naiman is located in the southwestern part of the Horqin Sandy Land (Fig. 1), which is roughly $400 \mathrm{~km} \times 400$ $\mathrm{km}$ in size and represents the most desertification-threatened area in northeastern China. The landscape is characterized by sand dunes alternating with gently undulating valley bottoms between dunes ( $\mathrm{Li}$ et al., 2005a). The soil is sandy and particularly susceptible to wind erosion ( $\mathrm{Li}$ et al., 2005a), and the region belongs to the temperate zone, with a continental semi-arid monsoon climate. Mean annual precipitation from 1961 to 2000 was $366 \mathrm{~mm}$ with high seasonal variability. The mean annual potential evaporation is as high as $1,935 \mathrm{~mm}$, due to windy conditions and high summer temperatures. The annual mean temperature is about $6.7^{\circ} \mathrm{C}$, and the lowest and highest monthly mean temperatures are $-12.6^{\circ} \mathrm{C}$ in January and $24.3^{\circ} \mathrm{C}$ in July, respectively.

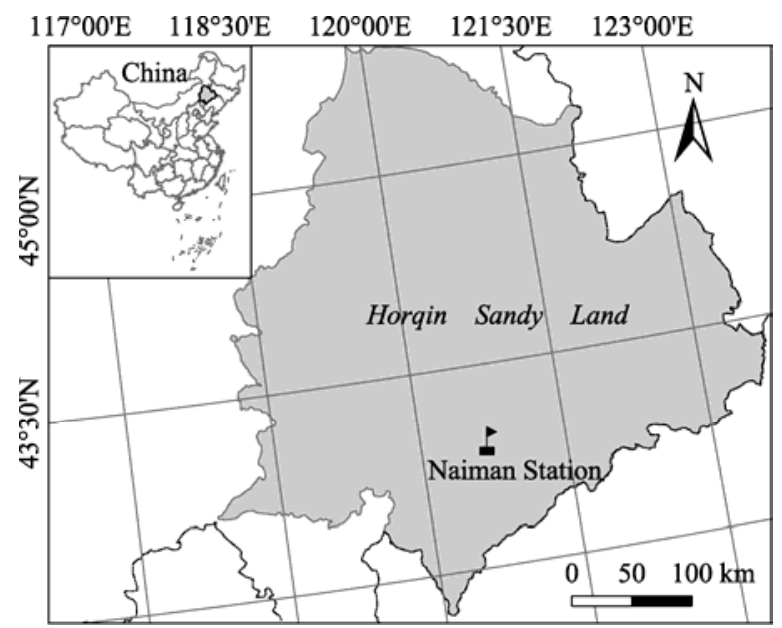

Fig. 1 Location of Horqin Sandy Land and the Naiman Desertification and Farmland Research Station in China

In this study, mobile dune, fixed dune and restored grassland, which represent different steps in the restoration of mobile dunes, were compared. We classified these biotopes according to soil crust presence and vegetation characteristics: soil crust in mobile dune is absent and shifting sand covers about $100 \%$, while soil crust covers more than $20 \%$ and shifting sand less than $10 \%$ in fixed dune, and there is nearly $100 \%$ soil crust and no shifting sand in grassland. Vegetation characteristics for these biotopes are documented in earlier reports ( $\mathrm{Li}$ et al., 2006; Zuo et al., 2012a, b).

\subsection{Soil sampling and treatments}

Soil samples were collected from three different biotopes (grassland, fixed dune and mobile dune) in the Horqin grassland area in June 2012. In each biotope, 5 plots (20 m×20 m) were selected and the distance between plots ranged from 1 to $3 \mathrm{~km}$. After removal of surface litter, surface soils $(0-10 \mathrm{~cm})$ from 3 sampling points (spacing about 5 meters) per plot were sampled by soil core (diameter $28 \mathrm{~mm}$ ) and mixed together. After bulking and thorough mixing, the soil samples were divided into two parts, one was used for the incubation experiment and another for soil chemical analysis (Table 1). One core sample in each plot was taken for measuring soil saturation water capacity and water content.

The mixed soil samples were placed in plastic bags and taken to the laboratory, and the samples were sieved with a 2-mm mesh to remove gravel and larger litter. Soil chemical properties (Table 1) were measured using standard methodologies: soil $\mathrm{pH}$ was determined in a 1:2.5 (w/w) and electrical conductivity in a $1: 5(\mathrm{w} / \mathrm{w})$ soil:water suspension at $25^{\circ} \mathrm{C}$ (Multiline F/SET-3; WTW, Weilheim, Germany); soil total organic carbon using the Walkley-Black dichromate oxidation method (Nelson and Sommers, 1982); total $\mathrm{N}$ using the Kjeldahl method (McGill and Figueiredo, 1993); total $\mathrm{P}$ and total K by Mo-Sb antispectrophotography method and flare photometer method (ISSCAS, 1978); available P using the Olsen method (Olsen et al., 1954); available $\mathrm{N}$ by the alkaline diffusion method, and available $\mathrm{K}$ was extracted with $1 \mathrm{M}$ ammonium acetate and measured by atomic absorption spectroscopy (ISSCAS, 1978).

Three artificial root exudates, citric acid, glucose and oxalic acid, were added in aqueous solution to each biotope soil (3 biotopes $\times 5$ plots $\times 4$ treatments including control $=60$ units) at a concentration of 600 mg C/kg dry soil. After exudate addition, soil water content was adjusted to $60 \%$ of saturation water capacity, and the soil samples were placed in a constant temperature incubator for equilibration at $25^{\circ} \mathrm{C}$ in darkness for $24 \mathrm{~h}$ before starting the measurements. 


\subsection{Measurement of carbon mineralization}

After equilibration, $20 \mathrm{~g}$ fresh soil was placed in 500 $\mathrm{mL}$ glass jars which contained a vial with $10 \mathrm{~mL}$ of $0.2 \mathrm{M} \mathrm{NaOH}$ to absorb the $\mathrm{CO}_{2}$ released from the soils during incubation. Each treatment had 5 replicates, and all 60 jars were placed in the laboratory at $25 \pm 2^{\circ} \mathrm{C}$. After incubation, the remaining $\mathrm{NaOH}$ was titrated with $0.1 \mathrm{M} \mathrm{HCl}$ to determine the amount of $\mathrm{CO}_{2}$ produced (Tian et al., 2010). Accumulated $\mathrm{CO}_{2}$ release was measured after 3, 6, 9, 12, 15, 18, 21 and 24 days of incubation, respectively.

\subsection{Statistical analysis}

Statistical analysis was conducted using SPSS (SPSS 13.0). Soil properties and $\mathrm{CO}_{2}-\mathrm{C}$ dynamics with the different treatments were generally analyzed by one-way ANOVA. Multiple comparisons using the LSD test were done whenever the ANOVA indicated significant differences $(P \leq 0.05)$. The data of total $\mathrm{CO}_{2}-\mathrm{C}$ emission, soil $\mathrm{pH}$ and electrical conductivity with the different treatments and biotopes as factors were analyzed by two-way ANOVA.

\section{Results}

\subsection{Soil properties}

Soil organic carbon (SOC) content was as expected very low in the mobile dune soil $(0.2 \mathrm{~g} / \mathrm{kg})$, and the $\mathrm{C} / \mathrm{N}$ ratio was below 5 (Table 1 ). The fixed dune had an intermediate SOC content and a $\mathrm{C} / \mathrm{N}$ ratio close to that in grassland. Available $\mathrm{N}$ constituted a smaller part of total $\mathrm{N}$ in grassland, indicating a more refrac- tory SOM. Available P showed similar tendencies, with the highest proportion in the mobile dune. Available $\mathrm{K}$ was low in mobile dune, and this was true also for electrical conductivity. Saturation water capacity was also high in grassland and low in mobile dune. The three biotopes had an alkaline reaction, with $\mathrm{pH}$ ranging from 8.2 to 8.5 .

\subsection{Soil organic carbon mineralization}

\subsubsection{Control treatment}

In the control treatment, grassland SOC mineralization rates were significantly $(P<0.05)$ higher than those in soils from fixed and mobile dunes (Fig. 2). During the initial three days of incubation, the mean value was $10.62 \mathrm{mg} /(\mathrm{kg} \cdot \mathrm{d})$, which decreased to $6.26 \mathrm{mg} /(\mathrm{kg} \cdot \mathrm{d})$ on D6. In the fixed dune, SOC mineralization rates were lower, with the maximum and the minimum at $5.25 \mathrm{mg} /(\mathrm{kg} \cdot \mathrm{d})$ on D3 and $1.10 \mathrm{mg} /(\mathrm{kg} \cdot \mathrm{d})$ on D24, respectively. Average SOC mineralization rates in mobile dune were $1.40 \mathrm{mg} /(\mathrm{kg} \cdot \mathrm{d})$, lower than those in fixed dune and grassland, which were 2.45 and 4.80 $\mathrm{mg} /(\mathrm{kg} \cdot \mathrm{d})$, respectively. However, mobile dune had only $3.7 \%$ of the SOC content in grassland (Table 1) and the amount respired compared with that of grassland (1.4/4.8) was much closer, indicating that SOC in mobile dune was much less stable than that in more normal soils.

\subsubsection{Glucose addition}

In grassland and fixed dune soils, $\mathrm{CO}_{2}$-C emissions were high during the initial 3 days of incubation and then decreased. Thereafter, the carbon mineralization rate decreased and then became stable in grassland

Table 1 Soil properties in the three biotopes $(0-10 \mathrm{~cm}$ depth, mean $\pm \mathrm{SE}, n=5)$ before incubation

\begin{tabular}{lccc}
\hline & Grassland & Fixed dune & Mobile dune \\
\hline Total organic carbon $(\mathrm{g} / \mathrm{kg})$ & $5.31 \pm 0.55$ & $1.58 \pm 0.17$ & $0.20 \pm 0.04$ \\
Total nitrogen $(\mathrm{mg} / \mathrm{kg})$ & $540.71 \pm 92.85$ & $177.95 \pm 16.99$ & $44.59 \pm 5.57$ \\
C/N ratio & 10.12 & 8.90 & 4.62 \\
Available nitrogen $(\mathrm{mg} / \mathrm{kg})$ & $40.25 \pm 1.66$ & $36.31 \pm 4.16$ & $11.81 \pm 1.36$ \\
Total phosphorus $(\mathrm{mg} / \mathrm{kg})$ & $424.65 \pm 10.77$ & $216.15 \pm 23.82$ & $77.08 \pm 4.23$ \\
Available phosphorus $(\mathrm{mg} / \mathrm{kg})$ & $14.44 \pm 1.51$ & $9.62 \pm 1.16$ & $6.61 \pm 0.89$ \\
Total potassium $(\mathrm{g} / \mathrm{kg})$ & $22.67 \pm 0.33$ & $18.67 \pm 0.33$ & $20.33 \pm 0.33$ \\
Available potassium $(\mathrm{mg} / \mathrm{kg})$ & $166.67 \pm 8.82$ & $206.67 \pm 29.06$ & $46.67 \pm 3.33$ \\
pH (1: 2.5 water) & $8.50 \pm 0.10$ & $8.22 \pm 0.23$ & $8.33 \pm 0.10$ \\
Electrical conductivity $(1: 5$ water, $\mu \mathrm{S} / \mathrm{cm})$ & $45.00 \pm 1.53$ & $46.33 \pm 6.44$ & $13.33 \pm 2.96$ \\
Saturation water capacity $(\%)$ & $25.44 \pm 1.28$ & $21.19 \pm 0.54$ & $16.17 \pm 0.17$ \\
\hline
\end{tabular}



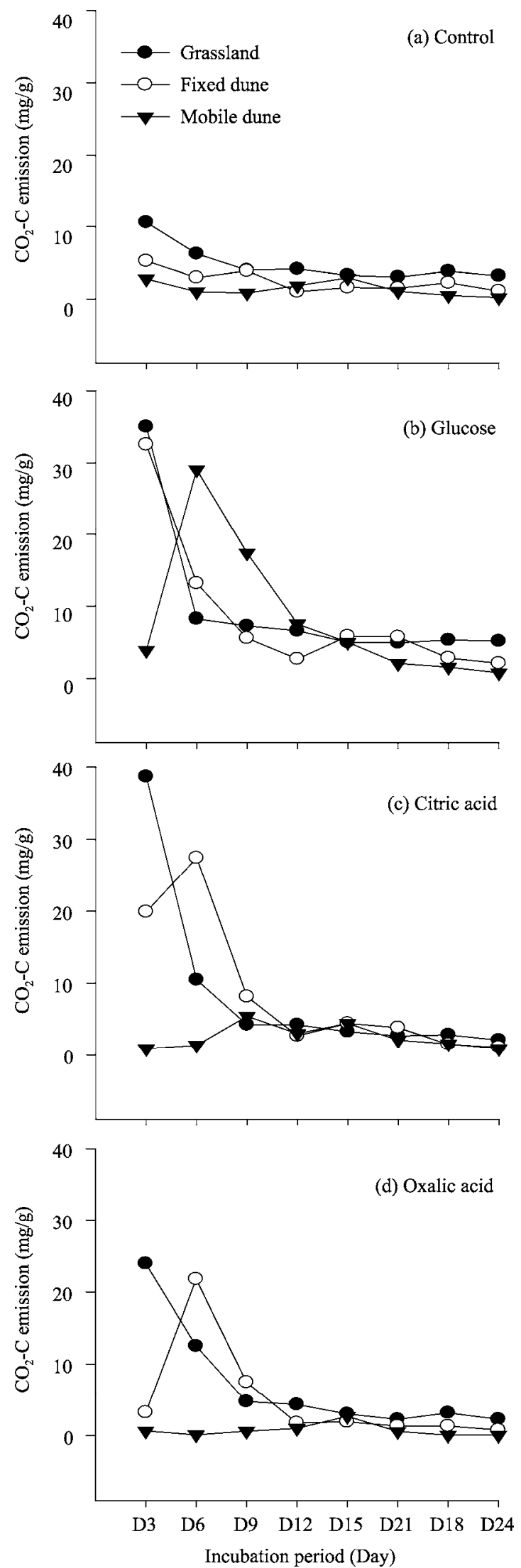

Fig. $2 \mathrm{CO}_{2}-\mathrm{C}$ emission dynamics during the 24-d incubation, $n=5$. soil. In fixed dune soil, carbon mineralization behaved similarly, but fluctuated more than that in grassland soil. In mobile dune soil, there was a lag phase after the addition of glucose, and the highest emission was observed on D6. Thereafter, the emission rate in mobile dune soil decreased almost down to zero at the end of incubation.

\subsubsection{Oxalic and citric acid addition}

Both acids induced similar responses (Fig. 2). In grassland, the acids behaved as glucose, with an early maximum that gradually decreased. In fixed dune, a lag phase could be detected in both treatments, with the maximum emission on D6. In mobile dune, SOC mineralization rates were not very different from the control, but a tendency for a lag phase can be detected in the citric acid treatment.

\subsubsection{Comparison of accumulated respiration}

The total $\mathrm{CO}_{2}$-C emissions (Fig. 3) sum up the dynamics shown in Fig. 2, which also was affected by biotopes, treatments and interactions between the above mentioned factors (Table 2). Carbon mineralization in grassland soil was higher than in fixed and mobile dune soils in all four treatments, and that in mobile dune was as expected lowest. Average $\mathrm{CO}_{2}-\mathrm{C}$ emission in grassland soil was $171.2 \mathrm{mg} / \mathrm{kg}$, and 145.4 and $75.2 \mathrm{mg} / \mathrm{kg}$ in fixed dune and mobile dune soils, respectively. Only glucose addition had a major effect on total respiration in mobile dune soil, while the organic acids only had a small influence in spite of containing $600 \mathrm{mg} / \mathrm{kg}$ of carbon.

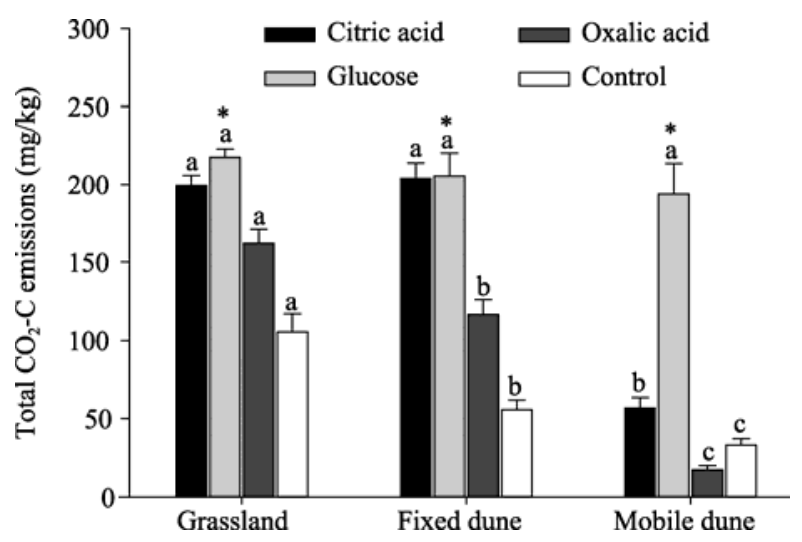

Fig. 3 Accumulated $\mathrm{CO}_{2}-\mathrm{C}$ emissions after 24 days of incubation, $n=5$. * indicates significant differences $(P<0.01)$ between treatments and different letters above the bar indicate significant differences $(P<0.05)$ between biotopes in each treatment. 
Table 2 Results from two-way ANOVA of the effect of biotopes and treatments on total $\mathrm{CO}_{2}$ emission, $\mathrm{pH}$ and electrical conductivity

\begin{tabular}{|c|c|c|c|c|c|c|c|}
\hline \multirow{2}{*}{ Source } & \multirow{2}{*}{$d f$} & \multicolumn{2}{|c|}{ Total $\mathrm{CO}_{2}$ emission } & \multicolumn{2}{|c|}{$\mathrm{pH}$} & \multicolumn{2}{|c|}{ Electrical conductivity } \\
\hline & & Mean square & $F$ & Mean square & $F$ & Mean square & $F$ \\
\hline Biotope (B) & 2 & $49,331.64$ & $498.60^{* *}$ & 39.87 & $5,069.50^{* *}$ & $4,715.55$ & $126.96^{* *}$ \\
\hline Treatment (T) & 3 & $57,551.07$ & $581.67^{* *}$ & 3.92 & $498.56^{* *}$ & $3,325.53$ & $89.54^{* *}$ \\
\hline $\mathrm{B} \times \mathrm{T}$ & 6 & $6,923.71$ & $69.98^{* * *}$ & 5.74 & $729.58^{* *}$ & $2,263.15$ & $60.93^{* *}$ \\
\hline
\end{tabular}

Note: ** means the significant difference at the level of 0.001 .

If we assume that the added substrates did not affect SOC mineralization, i.e. no "priming" (see Gärdenäs et al., 2011), we can calculate the fraction of added substrate carbon, $600 \mathrm{mg} / \mathrm{kg}$, that was respired during the incubation. However, the soil respiration in the control treatment has to be subtracted from the total. For glucose addition, the proportions respired in the grassland, fixed dune and mobile dune were $22 \%$, $29 \%$ and 30\%, respectively (Fig. 3). Citric acid, in contrast, was decomposed to only about $18 \%, 28 \%$ and $4 \%$ in the grassland, fixed dune and mobile dune, respectively, while oxalic acid was decomposed to $11 \%, 12 \%$ and $-3 \%$ (indicating reduced decomposition of native SOC), respectively.

A potential priming effect cannot be excluded in this study, but without labeling either the substrate or native carbon using techniques such as isotope cannot be established (Andrén et al., 2008). The addition of oxalic acid to mobile dune soil resulted in a lower emission than in the control, which probably was due to the reduction in $\mathrm{pH}$ to 4.77 (Table 4).

Comparing the total emissions without separating exudate and native carbon, i.e. comparing the total microbial respiration with or without added exudates, a few observations can be made (Fig. 3, Table 3). The lower carbon content and consequential lower carbon emission from fixed dune compared with grassland creates an apparently much higher increase in the total microbial respiration. In mobile dune, glucose addition creates a five-fold increase, again due to the low control. Total $\mathrm{CO}_{2}$ emission in mobile dune was reduced by almost half by oxalic acid addition (Table 3).

Table 3 Percentage of increase in total SOC mineralization after treatments compared with the control

\begin{tabular}{lccc}
\hline Biotype & Citric acid & Glucose & Oxalic acid \\
\hline Grassland & 88.98 & 106.19 & 53.49 \\
Fixed dune & 267.33 & 270.06 & 109.98 \\
Mobile dune & 70.91 & 485.40 & -47.71 \\
\hline
\end{tabular}

\subsection{Changes in acidity and electrical conductivity}

Similar to total $\mathrm{CO}_{2}$ emission, soil $\mathrm{pH}$ and electrical conductivity were significantly affected by biotopes, treatments and their interaction (Table 2). After 24 days of incubation without added substrate, $\mathrm{pH}$ values increased slightly in grassland and fixed dune soil and decreased somewhat in mobile dune soil (Table 4) compared with the initial soil pH (Table 1). An increase was also observed when the soils were amended with citric acid, glucose or oxalic acid, in both grassland and fixed dune soils. Acid addition increased the $\mathrm{pH}$ slightly more than glucose addition in both grassland and fixed dune biotopes. In mobile dune soil responses were quite different, i.e. glucose addition decreased $\mathrm{pH}$ compared to the control, and the organic acids drastically reduced pH to below 5 .

Initial soil electrical conductivity was showed in Table 1, which was also affected by treatments, biotopes and their interaction (Table 2). In the control, electrical conductivity increased somewhat in all biotopes, but organic acid addition to mobile dune soil greatly increased the soil electrical conductivity (Fig. 4).

Table 4 Effects of 24 days of incubation and addition of exudates on acidity ( $\mathrm{pH}$ values, mean $\pm \mathrm{SE}, n=5$ )

\begin{tabular}{llll}
\hline & Grassland & Fixed dune & Mobile dune \\
\hline Citric acid & $9.08 \pm 0.06^{\mathrm{Aa}}$ & $8.58 \pm 0.10^{\mathrm{Ab}}$ & $4.89 \pm 0.18^{\mathrm{Cc}}$ \\
Glucose & $8.93 \pm 0.06^{\mathrm{Ba}}$ & $8.59 \pm 0.03^{\mathrm{Ab}}$ & $7.59 \pm 0.15^{\mathrm{Bc}}$ \\
Oxalic acid & $9.05 \pm 0.02^{\mathrm{Aa}}$ & $8.62 \pm 0.06^{\mathrm{Ab}}$ & $4.77 \pm 0.05^{\mathrm{Cc}}$ \\
Control & $8.78 \pm 0.04^{\mathrm{Ca}}$ & $8.33 \pm 0.08^{\mathrm{Bb}}$ & $8.07 \pm 0.09^{\mathrm{Ac}}$ \\
\hline
\end{tabular}

Note: Values with different capital letters differ between treatments; those with different lower case letters differ between biotopes $(P<0.05)$.

\section{Discussion}

Clearly, the different degrees of degradation at the site were reflected in the soil properties, where a shortage of organic matter characterized the mobile dune (Table 1). 
A similar pattern from Horqin Sandy Land was observed by Li et al. (2005), who reported carbon and nitrogen concentrations of 5.17 and $0.55 \mathrm{~g} / \mathrm{kg}$, respectively, in grassland; 2.55 and $0.30 \mathrm{~g} / \mathrm{kg}$ in fixed dune, and 0.49 and $0.072 \mathrm{~g} / \mathrm{kg}$ in mobile dune. $\mathrm{C} / \mathrm{N}$ ratios were 9.37 in grassland, 8.52 in fixed dune and 6.84 in mobile dune, respectively. Compared with the present investigation, these values are fairly similar, with one exception, i.e. in mobile dune carbon content was twice that measured here and $\mathrm{C} / \mathrm{N}$ ratio was also higher.

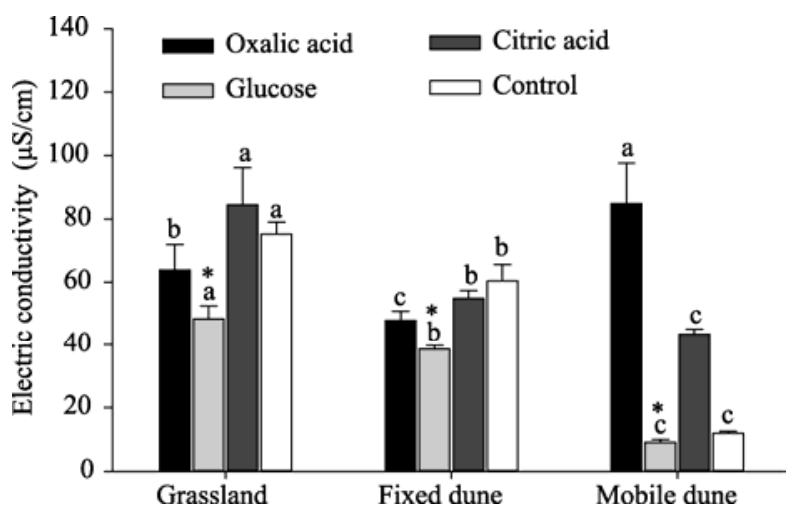

Fig. 4 Electrical conductivity after 24 days of incubation, $n=5$. * indicates significant differences $(P<0.01)$ between treatments and different letters above the bar indicate significant differences $(P<0.05)$ between biotopes in each treatment.

However, the very low carbon content in mobile dune makes general comparisons and conclusions difficult, i.e. local and recent history such as aeolian input of litter particles etc. will affect the results. The low input through lower or absent vegetation cover is a major factor (Zuo et al., 2008, 2012), but the lack of humus formation also contributes. Litter carried into the dune by wind is ground to dust and carried away by wind and to some extent photooxidized ( $\mathrm{Li}$ et al., 2005b), resulting in low SOC contents. The lower proportions of available $\mathrm{N}$ and available $\mathrm{P}$ in the vegetated biotopes further support the observation that SOC in moving dunes show a low degree of humification. The low SOC concentration in mobile dune and the consequential lack of buffering capacity also explain the drastic effects of adding organic acids, i.e. a decrease in $\mathrm{pH}$ from about 8.5 to below 5 (Table 4). On the other hand, organic acid addition led to a small but significant increase in $\mathrm{pH}$ in the vegetated biotopes.
Soil electrical conductivity and $\mathrm{pH}$ varied significantly when amended by exudate compounds (Fig. 4, Table 4). Studies of $\mathrm{pH}$ changes in soils amended by low molecular weight compounds are rare, but studies of glucose and organic acid addition indicate similar results. Rukshana et al. (2012) added citric acid to soils differing in initial $\mathrm{pH}$, and soil $\mathrm{pH}$ decreased initially and recovered later. After three days, a Tenosol (initial $\mathrm{pH}$ 6.2) showed higher $\mathrm{pH}$ than the control in the citric acid treatment, while a Podosol (initial $\mathrm{pH}$ 4.5) showed continuously lower $\mathrm{pH}$ than the control. Rukshana et al. (2011) found that glucose had no immediate effect on soil $\mathrm{pH}$. However, in a later study by Rukshana et al. (2012), pH in a Tenosol increased a few days after glucose addition, and they suggested that the result was due to indigenous glucose decomposition or nitrate immobilization by microorganisms. The small but significant increase in $\mathrm{pH}$ reported here (Table 4) may have a similar explanation.

Addition of acids increased soil $\mathrm{pH}$, which was an unexpected phenomenon in general and few researches focused on this. It should be an explanation why rezosphere soil $\mathrm{pH}$ kept in a stable state in spite that live root produced acid compounds constantly.

In this study, there was a significant and positive linear relationship between total carbon mineralization and $\mathrm{pH}$ in both control (Fig. 5a) and amended soil (Fig. $5 b)$. This indicates that soil carbon mineralization increased the soil $\mathrm{pH}$. So the increase of soil $\mathrm{pH}$ may be the result of soil carbon mineralization.

In contrast to grassland and fixed dune soils, addition of acids in mobile dune decreased soil $\mathrm{pH}$. That may result from the low amount of SOC: in mobile dune soil, added SOC was triple of native SOC, so the buffering capacity (resistance to $\mathrm{pH}$ change) was lower than in the other biotopes. Thus, the acidity of the added citric or oxalic acid was not neutralized in the soil of mobile dune.

Carbonate in the soil will emit $\mathrm{CO}_{2}$ non-biologically when acidified and has to be taken into account. In Horqin Sandy Land, the carbonate carbon content was estimated to be $39-46 \mathrm{mg} / \mathrm{kg}$ in the top layer $(0-10$ $\mathrm{cm}$ ) of mobile dune soil, $71 \mathrm{mg} / \mathrm{kg}$ in fixed dune soil, and about $85 \mathrm{mg} / \mathrm{kg}$ in grassland (YuQiang LI, personal communication). Although not entirely negligible, these amounts and differences between biotopes cannot explain the differences seen in Fig. 3. 

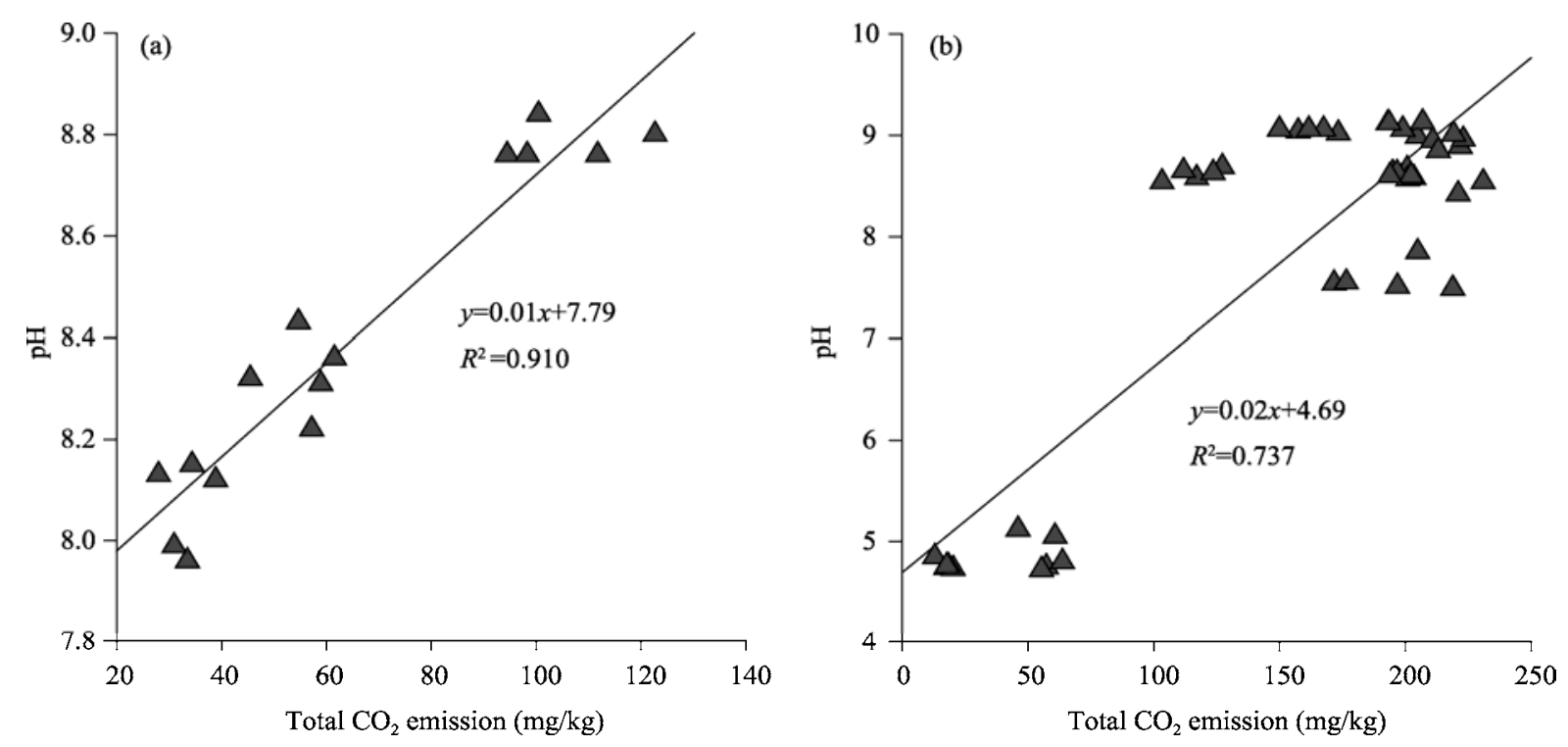

Fig. 5 Relationship between total $\mathrm{CO}_{2}$ emission (y) and $\mathrm{pH}(\mathrm{x})$ in the control $(\mathrm{a}, n=15)$ and amended (b, $\left.n=45\right)$ soils

In our study, soil respiration significantly increased when soils were amended with $600 \mathrm{mg} / \mathrm{kg}$ glucose. Landi et al. (2006) found that addition of glucose increased soil respiration, and the result was also evidenced by many other researchers. It is a well-known fact that glucose is excellent fuel for microorganisms. In all biotopes, the proportion of added glucose that was respired during the experiment was $22 \%-30 \%$, with the lower value found in the restored grassland when the control was subtracted from Glucose (Fig. 4). Thus there was no indication of a lower potential for decomposition of glucose in the low carbon mobile dune, i.e. the microbial community there seems to be sufficient. However, the lag phase in observed exudate-amended $\mathrm{CO}_{2}$ emissions in the incubation experiment (Fig. 3) may reflect an impoverished microflora in the mobile dune (Silvia et al., 2001), but with a capacity to within a few days to a week build up enough enzyme production to decompose the glucose.

Possible future developments are to refine the incubation experiment using soil microbial suspension from the grassland added to mobile dune soil, which will show if a more diverse and abundant microflora will decrease the lag phase and increase total respiration. Including isotopically labeled substrates (e.g. ${ }^{14} \mathrm{C}$ ) would address the question of priming, and using mobile dune soils under early stages of restoration, e.g. after wheat straw addition for stabilization (Zhang et al., 2004), will yield information on the role of plant exudates in the critical process of fixation of moving dunes.

\section{Conclusions}

The results from our study indicated that discrete components of root exudates affected soil environmental conditions and their effect also varied among biotopes. Addition of glucose increased soil respiration quickly in two biotopes and after a slight delay in mobile dune. Similar $\mathrm{CO}_{2}$ emission dynamics were observed after citric and oxalic acid addition, i.e. a rapid response in grassland, a slight delay in fixed dune but constant low activity in mobile dune. Both glucose and acid addition increased total $\mathrm{CO}_{2}$ emission, but the emission declined in mobile dune soil, indicating a potential for, e.g., acid root exudates to decrease the decomposition rate of soil organic matter in low carbon soils, which is of interest for both soil restoration and carbon sequestration. Due to SOC mineralization, $\mathrm{pH}$ increased in grassland and fixed dune soils. However, soil $\mathrm{pH}$ declined in mobile dune, especially in acid treatments, probably due to soil properties such as nutrient deficiency and low buffering capacity.

\section{Acknowledgments}

This work was financially supported by the National Natural Science Foundation of China (41071185, 31170413) and the National Basic Research Program of China (2011BAC07B02). Chinese Academy of Sciences has kindly granted Prof. Olof ANDRÉN a 'Professorship for Senior International Scientists' 
(Y229D91001), which made his participation possible. We thank our colleagues at Naiman Desertification Research Station, Chinese Academy of Sciences, for their help in laboratory analysis. We also thank the three reviewers for their valuable comments on this paper.

\section{References}

Abera G, Wolde-meskel E, Bakken L R. 2012. Carbon and nitrogen mineralization dynamics in different soils of the tropics amended with legume residues and contrasting soil moisture contents. Biology and Fertility of Soils, 48: 51-66.

Andrén O, Zhao X Y, Liu X M. 1994. Climate and litter decomposition in Naiman, Inner Mongolia, China. Ambio, 23: 222-224.

Andrén O, Kirchmann H, Kätterer T, et al. 2008. Visions of a more precise soil biology. European Journal of Soil Science, 59: 380-390.

Chen Y P, Li Y Q, Awada T, et al. 2012. Carbon sequestration in the total and light fraction soil organic matter along a chronosequence in grazing exclosures in a semiarid degraded sandy site in China. Journal of Arid Land, 4: 411-419.

Elhalmouch Y, Benharrat H, Thalouarn P. 2006. Effect of root exudates from different tomato genotypes on broomrape (O. aegyptiaca) seed germination and tubercle development. Crop Protection, 25: 501-507.

Gadkar V, David-Schwartz R, Nagahashi G, et al. 2003. Root exudate of pmi tomato mutant M161 reduces AM fungal proliferation in vitro. FEMS Microbiology Letter, 223: 193-198.

Gärdenäs A I, Ågren G I, Bird J A, et al. 2011. Knowledge gaps in soil carbon and nitrogen interactions-From molecular to global scale. Soil Biology and Biochemistry, 43: 702-717.

Glanville H, Rousk J, Golyshin P, et al. 2012. Mineralization of low molecular weight carbon substrates in soil solution under laboratory and field conditions. Soil Biology and Biochemistry, 48: 88-95.

Gregory P J. 2006. Plant root. Growth, Activity and Interaction with Soil. Oxford: Blackwell Publishing, 216-222.

Hao Z, Wang Q, Christie P, et al. 2007. Allelopathic potential of watermelon tissues and root exudates. Scientia Horticulturae, 112: 315-320.

ISSCAS (Institute of Soil Sciences, Chinese Academy of Sciences). 1978. Physical and Chemical Analysis Methods of Soils. Shanghai: Shanghai Science Technology Press, 7-59.

Khan M A, Cheng Z H, Xiao X M, et al. 2011. Ultrastructural studies of the inhibition effect against Phytophthora capsici of root exudates collected from two garlic cultivars along with their qualitative analysis. Crop Protection, 30: 1149-1155.

Landi L, Valori F, Ascher J, et al. 2006. Root exudate effects on the bacterial communities, $\mathrm{CO}_{2}$ evolution, nitrogen transformations and ATP content of rhizosphere and bulk soils. Soil Biology and Biochemistry, 38: 509-516.

Li F R, Zhang A S, Duan S S, et al. 2005a. Patterns of reproductive allocation in Artemisia halodendron inhabiting two contrasting habitats. Acta Oecologica. 28: 57-64.

Li F R, Wang T, Zhang A S, et al. 2005b. Wind-dispersed seed deposition patterns and seedling recruitment of Artemisia halodendron in a moving sandy land. Annals of Botany, 96: 69-80.

Li Y, Zhao H, Zhao X, et al. 2006. Biomass energy, carbon and nitrogen stores in different habitats along a desertification gradient in the semiarid Horqin Sandy Land. Arid Land Research and Management, 20: 43-60.

Li Y Q, Zhao H L, Zhao X Y, et al. 2005. Characteristics of soil carbon and nitrogen during desertification process in Horqin Sandy Land. Journal of Soil Water Conservation, 19: 73-76.

McGill W B, Figueiredo C T. 1993. Total nitrogen. In: Carter M R. Soil Sampling and Methods of Analysis. Canadian Society of Soil Science. Boca Raton: Lewis Publishers, 201-211.

Nelson D W, Sommers L E. 1982. Total carbon, organic carbon and organic matter. In: Page A L, Miller R H, Keeney D R. Methods of Soil Analysis, $2^{\text {nd }}$ ed. Madison: American Society of Agronomy, 539-577.

Olsen S R, Cole C W, Watanabe F S, et al. 1954. Estimation of available phosphorus in soils by extraction with sodium bicarbonate. U.S. Department of Agriculture. Circular No.: 939.

Ren L, Su S, Yang X, et al. 2008. Intercropping with aerobic rice suppressed Fusarium wilt in watermelon. Soil Biology and Biochemistry, 40: 834-844.

Rukshana F, Butterly C R, Baldock J A, et al. 2011. Model organic compounds differ in their effects on $\mathrm{pH}$ changes of two soils differing in initial pH. Biology and Fertility of Soils, 47: 51-62.

Rukshana F, Butterly C R, Baldock J A, et al. 2012. Model organic compounds differ in priming effects on alkalinity release in soils through carbon and nitrogen mineralisation. Soil Biology and Biochemistry, 51: 35-43.

Silvia N, Angelina M Y, Alberto B, et al. 2001. Carbon mineralization in the southern Sonoran Desert. Acta Oecologica, 22: 269-276.

Strickland M S, Wickings K, Bradford M A. 2012. The fate of glucose, a low molecular weight compound of root exudates, in the belowground foodweb of forests and pastures. Soil Biology and Biochemistry, 49: 23-29.

Sturz A V, Christie B R. 2003. Beneficial microbial allelopathies in the root zone: the management of soil quality and plant disease with rhizobacteria. Soil and Tillage Research, 72: 107-123.

Tian L, Dell E, Shi W. 2010. Chemical composition of dissolved organic matter in agroecosystems: correlations with soil enzyme activity and carbon and nitrogen mineralization. Applied Soil Ecology, 46: 426-435.

van Hees P A W, Jones D L, Finlay R, et al. 2005. The carbon we do not see-the impact of low molecular weight compounds on carbon dynamics and respiration in forest soils: a review. Soil Biology and Biochemistry, 37: 1-13.

Yu J Q, Ye S F, Zhang M F, et al. 2003. Effects of root exudates and aqueous root extracts of cucumber (Cucumis sativus) and allelochemicals, on photosynthesis and antioxidant enzymes in $\mathrm{cu}-$ cumber. Biochemical Systematics and Ecology, 31: 129-139.

Zhang T H, Zhao H L, Li S G, et al. 2004. A comparison of different measures for stabilizing moving sand dunes in the Horqin Sandy Land of Inner Mongolia, China. Journal of Arid Environments, 58: 203-214.

Zhou N, Liu P, Wang Z Y, et al. 2011. The effects of rapeseed root exudates on the forms of aluminum in aluminum stressed rhizosphere soil. Crop Protection, 30: 631-636.

Zuo X A, Zhao H L, Zhao X Y, et al. 2008. Vegetation pattern variation, soil degradation and their relationship along a grassland desertification gradient in Horqin Sandy Land, northern China. Environmental Geology, 58: 1227-1237.

Zuo X A, Zhao X Y, Wang S K, et al. 2012a. Influence of dune stabilization on relationship between plant diversity and productivity in Horqin Sand Land, Northern China. Environmental Earth Science, 67: 1547-1556.

Zuo X A, Knops J M H, Zhao X Y, et al. 2012b. Indirect drivers of plant diversity-productivity relationship in semi-arid sandy grasslands. Biogeosciences, 9: 1277-1289. 